Published in final edited form as:

ACS Chem Biol. 2015 June 19; 10(6): 1404-1410. doi:10.1021/acschembio.5b00170.

\title{
Constructing de $\mathrm{Novo}_{2} \mathrm{O}_{2}$ Signaling via Induced Protein Proximity
}

\author{
Guihua Zeng, Roushu Zhang, Weimin Xuan, Wei Wang, and Fu-Sen Liang* \\ Department of Chemistry and Chemical Biology, University of New Mexico, Albuquerque, New \\ Mexico 87131, United States
}

\begin{abstract}
A new chemical strategy has been developed to generate de novo signaling pathways that link a signaling molecule, $\mathrm{H}_{2} \mathrm{O}_{2}$, to different downstream cellular events in mammalian cells. This approach combines the reactivity-based $\mathrm{H}_{2} \mathrm{O}_{2}$ sensing with the chemically induced protein proximity technology. By chemically modifying abscisic acid with an $\mathrm{H}_{2} \mathrm{O}_{2}$-sensitive boronate ester probe, novel $\mathrm{H}_{2} \mathrm{O}_{2}$ signaling pathways can be engineered to induce transcription, protein translocation and membrane ruffle formation upon exogenous or endogenous $\mathrm{H}_{2} \mathrm{O}_{2}$ stimulation. This strategy has also been successfully applied to gibberellic acid, which provides the potential to build signaling networks based on orthogonal cell stimuli.
\end{abstract}

\section{Graphical Abstract}

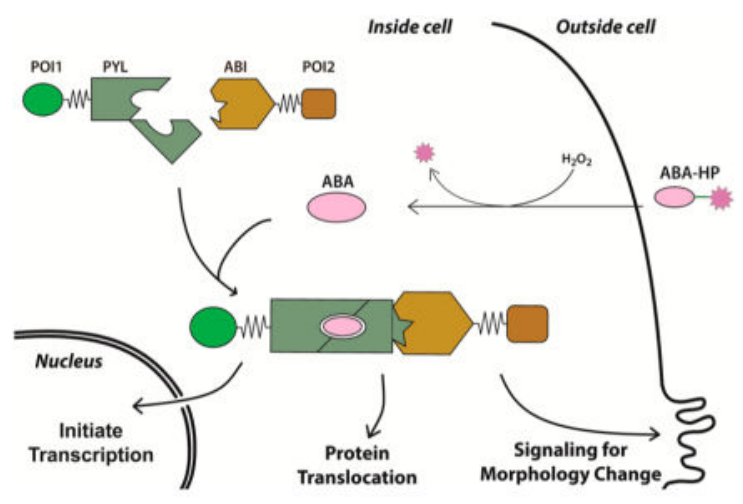

\footnotetext{
Nature evolves sophisticated cell signaling circuits that convert perceived environmental signals into proper cellular responses to maintain normal function of cells. Recent efforts have been dedicated to engineer predictable and tailored cellular functions in response to detected stimuli by rewiring or creating synthetic signal transduction pathways. ${ }^{1-3}$ These efforts contribute to the understanding of how sophisticated cellular functions and behaviors

Methods and additional figures as described in the text. This material is available free of charge via the Internet at http://pubs.acs.org.
}

*Corresponding Author fsliang@unm.edu.

Notes

The authors declare no competing financial interest.

Supporting Information 
are built and hold great promise for biological computing ${ }^{4,5}$ and novel therapeutic applications. ${ }^{6,7}$

To create a synthetic signaling pathway, one needs to consider how to create a sensing unit that can recognize only the chosen signal, how to transmit and process the detected signal, and how to link a processed decision to a desired functional output. Most of the current methods to engineer synthetic pathways that respond to cellular signals rely on either rewiring nature-evolved pathways or creating de novo synthetic pathways by evolving and selecting novel signaling parts. ${ }^{8}$ The first approach requires extensive knowledge of native cell signaling pathways and is limited to existing pathways in nature. The second approach can potentially provide unlimited possibility in constructing new signaling pathways. However, it requires substantial efforts and may still not obtain functional products as desired. The engineering information that is gained is also less likely to be transferable to the design of a new signaling component.

The chemically induced proximity (CIP), or chemically induced dimerization (CID), technology has been developed to regulate biological processes using exogenous chemical inducers. ${ }^{9}$ Each CIP inducer triggers the association between two unique inducer-binding adaptor proteins that are fused individually to two other proteins of interest (POIs). Depending on the choice of POIs, it has been shown that different types of downstream biological events can be triggered by the stimulation of these exogenous inducers. ${ }^{9-11}$ This technology provides a rapid and modular way to create novel CIP inducer-responsive synthetic signaling pathways. Several orthogonal CIP systems using different chemical inducers, including rapamycin, abscisic acid (ABA), gibberellic acid (GA), and other synthetic ligands, ${ }^{9,12,13}$ have been developed for broad biological applications.

$\mathrm{H}_{2} \mathrm{O}_{2}$ is a member of the reactive oxygen species (ROS) and an important diffusible secondary messenger in biological systems. ${ }^{14}$ It plays critical roles in several biological processes (e.g., signal transduction, cell differentiation, and apoptosis) and human diseases (e.g., cancer and neurodegenerative diseases). ${ }^{15-19}$ Here, we report a novel chemical strategy to create de novo $\mathrm{H}_{2} \mathrm{O}_{2}$ signaling pathways that can be tailored to give desired downstream biological outcomes by integrating the CIP methods and the $\mathrm{H}_{2} \mathrm{O}_{2}$ sensing technology. We showed that new signaling pathways can be engineered to link the $\mathrm{H}_{2} \mathrm{O}_{2}$ signal to otherwise unrelated cellular processes, including expression of chosen genes, translocation of chosen proteins, and remodeling of cytoskeleton through activating endogenous Rac1 signaling.

In the design of an $\mathrm{H}_{2} \mathrm{O}_{2}$-signaling inducer, an $\mathrm{H}_{2} \mathrm{O}_{2}$ responsive masking group is incorporated into a CIP inducer to abolish the protein dimerization ability of the inducer. It is expected that the modified inducer remains inactive until being exposed to $\mathrm{H}_{2} \mathrm{O}_{2} \cdot \mathrm{H}_{2} \mathrm{O}_{2}$ then promotes the chemical cleavage of the masking group to regenerate the original CIP inducer that triggers the predesigned biological effects (Figure 1A).

To explore the feasibility of this strategy, we first focused on the ABA CIP system that we developed. ${ }^{12}$ ABA binds selectively to the PYL protein and causes a conformational change of PYL to create a surface that can subsequently bind the ABI protein. On the basis of the crystal structure, ABA is totally embedded within the PYL pocket where it makes extensive 
contacts. ${ }^{20}$ We hypothesize that any chemical modification of ABA will likely disrupt its binding to PYL and therefore abolish the induced association between PYL and ABI. By modifying ABA with a chemical moiety that can be removed by $\mathrm{H}_{2} \mathrm{O}_{2}$, the ABA-based CIP activity should then be controlled by $\mathrm{H}_{2} \mathrm{O}_{2}$. We have recently shown that modifications at the carboxylic acid group on ABA, which engages in critical hydrogen bonding to PYL, ${ }^{20}$ disrupted the CIP activity of the caged ABA. ${ }^{21}$ We expect that a similar strategy can be used to install an $\mathrm{H}_{2} \mathrm{O}_{2}$-sensing unit onto $\mathrm{ABA}$ to mask its CIP activity. Several $\mathrm{H}_{2} \mathrm{O}_{2}$-responsive fluorescent probes have been developed. ${ }^{22} \mathrm{H}_{2} \mathrm{O}_{2}$-inducible systems that control transcription or cellular targeting were also reported..$^{23,24}$ In these studies, a boronate ester moiety was used as the $\mathrm{H}_{2} \mathrm{O}_{2}$-sensing unit. We reason that when $\mathrm{ABA}$ is equipped with the same boronate ester moiety, the ABA-inducible CIP should then be controlled by $\mathrm{H}_{2} \mathrm{O}_{2}$.

To examine the feasibility of this strategy, we synthesized an $\mathrm{H}_{2} \mathrm{O}_{2}$-responsive boronateconjugated ABA, referred to as ABA-HP (Figure 1B), which is expected to convert back to ABA upon the exposure to $\mathrm{H}_{2} \mathrm{O}_{2}$ (Supplementary Figure S1) based on a reported oxidative cleavage mechanism. ${ }^{22}$ Monitored by HPLC, we observed that, without $\mathrm{H}_{2} \mathrm{O}_{2}$, ABA-HP was not hydrolyzed to give ABA in HEPES buffer at $37^{\circ} \mathrm{C}$ throughout the $24 \mathrm{~h}$ observation period (Figure 1C). A dimer was observed (based on mass spectrometry analysis, Supplementary Figures S2 and S3) during this incubation period, which was likely formed through the coordination between the electron deficient boron on ABA-HP with an oxygen lone pair on another molecule of ABA-HP. Upon the addition of $\mathrm{H}_{2} \mathrm{O}_{2}$, ABA-HP started to convert back to $\mathrm{ABA}$ within minutes, and the transformation was completed in $4 \mathrm{~h}$ (Figure $1 \mathrm{C}$ and Supplementary Figure S2). Following the cleavage process using HPLC, we observed that besides the regenerated ABA and the dimeric ABA-HP, another peak appeared, which was converted to ABA at later time points and was likely an intermediate of the conversion (Supplementary Figure S1). To confirm that the dimeric ABA-HP can be converted to ABA, we preincubated ABA-HP in HEPES buffer to form the dimer and then treated it with $\mathrm{H}_{2} \mathrm{O}_{2}$. We found that $\mathrm{ABA}$ can indeed be generated from this dimer (Supplementary Figure S4). Next, we tested the selectivity of ABA-HP toward $\mathrm{H}_{2} \mathrm{O}_{2}$ over other ROS, metal ions, and signaling molecules. ABA-HP was incubated with different molecules as indicated in Figure 1D for $4 \mathrm{~h}$, and the products were analyzed using HPLC. ABA-HP was found to be unreactive to all molecules tested at $100 \mu \mathrm{M}$ (Figure 1D, Supplementary Figures $\mathrm{S} 5$ and $\mathrm{S} 6$ ), except $\mathrm{Cu}^{+}$and $\mathrm{Cu}^{2+}$, which produced a minimal amount of cleavage but were later shown to have no effects at the more physiologically relevant concentration of $10 \mu \mathrm{M}$ (Figure 1D, Supplementary Figure S7).

To test if this strategy works in cells, we first investigated whether the $\mathrm{H}_{2} \mathrm{O}_{2}$ signal can be linked to activate transcription since most cell signaling events eventually lead to gene expression. We used an HEK293T stable cell line, in which enhanced GFP (EGFP) expression occurs only in the presence of functional ABA. ${ }^{21}$ This cell line has both the ABA-responsive split transcriptional activator DNA fragment (VP-PYL and GAL4DBDABI linked by IRES) ${ }^{12}$ and an inducible EGFP DNA fragment (with 5xUAS) inserted into the genome (Figure 2Ai). To determine if the ABA generated from the $\mathrm{H}_{2} \mathrm{O}_{2}$-induced cleavage of ABA-HP is biologically active, we tested its ability to induce EGFP expression in this HEK293T reporter cell line. We precleaved ABA-HP with $\mathrm{H}_{2} \mathrm{O}_{2}$ and added the resulting products to the HEK293T cells. After incubation for $7 \mathrm{~h}$, EGFP production was 
observed under a fluorescence microscope (Supplementary Figure S8). This result indicates that the regenerated $\mathrm{ABA}$ is indeed biologically active. On the contrary, uncleaved ABA-HP failed to induce EGFP expression, which confirmed that the boronate modification blocked the activity of ABA as expected. We next tested whether ABA-HP can respond to $\mathrm{H}_{2} \mathrm{O}_{2}$ in cell culture conditions and cause the gene expression to be activated by $\mathrm{H}_{2} \mathrm{O}_{2}$ in cells. It has been reported that the endogenous $\mathrm{H}_{2} \mathrm{O}_{2}$ concentrations of tissue samples vary from 10 to $100 \mu \mathrm{M}$ range and that the pathologic tissues usually have even higher levels of $\mathrm{H}_{2} \mathrm{O}_{2} .{ }^{25-29}$ We therefore tested the response of our system to $\mathrm{H}_{2} \mathrm{O}_{2}$ at micromolar concentrations in living cells. The HEK293T reporter cells were treated with no drug, $10 \mu \mathrm{M}$ ABA, ABA-HP, or ABA-HP plus 10, 50, or $100 \mu \mathrm{M} \mathrm{H}_{2} \mathrm{O}_{2}$ for 5 to $24 \mathrm{~h}$. The expression of EGFP was monitored at indicated time points using a fluorescence microscope. The EGFP expression was detected only when ABA, or ABA-HP plus $\mathrm{H}_{2} \mathrm{O}_{2}$, were added (Figure 2B, Supplementary Figure S9). These results confirm that the $\mathrm{H}_{2} \mathrm{O}_{2}$-induced cleavage of ABAHP generates functional ABA in situ. Notably, we observed differential levels of EGFP production when different amounts of $\mathrm{H}_{2} \mathrm{O}_{2}$ were added. The ABA CIP system is known to give a wide-range of dosage response. ${ }^{12}$ These results indicate that this dosage response can be reproduced in the ABA-based $\mathrm{H}_{2} \mathrm{O}_{2}$-inducible system. This property can be useful for converting differential levels of $\mathrm{H}_{2} \mathrm{O}_{2}$ signals into different levels of transcription activity.

One concern for the stability of ABA-HP in cells is the existence of an ester linkage in the molecule, which may be susceptible to the hydrolysis by cellular esterases. In the above experiments, only a minimal level of the EGFP expression was observed within a $10 \mathrm{~h}$ period following the addition of ABA-HP in the absence of $\mathrm{H}_{2} \mathrm{O}_{2}$ (Figure 2B). This result suggests that the rate of ABA built up from the esterase cleavage of ABA-HP may be much slower than the $\mathrm{H}_{2} \mathrm{O}_{2}$-promoted cleavage. We suspect that the bulky benzyl boronate moiety may contribute to the enhanced stability when compared to simple ester structures commonly used in pro-drugs. With an extended incubation period (24 h), the EGFP expression was indeed observed (Supplementary Figure S9). When using a more sensitive ABA-inducible luciferase reporter assay, ${ }^{12} \mathrm{ABA}-\mathrm{HP}$ alone indeed induced observable luciferase expression in a shorter time (within $6 \mathrm{~h}$ ), although free ABA induced a much higher expression of luciferase (Supplementary Figure S10). These results indicate that further structural modifications of the boronate probe (e.g., increasing structural bulkiness near the ester linkage $)^{30}$ will be required to increase the cellular stability of ABA-HP for applications requiring extended incubation periods.

Many signaling events are regulated through the dynamic subcellular translocation of proteins. To test if we can redirect the $\mathrm{H}_{2} \mathrm{O}_{2}$ signal to control protein translocation, we used a reported ABA-inducible EGFP nuclear export system consisting of NES-ABI and EGFPPYL DNA constructs (Figure 2Aii). ${ }^{12} \mathrm{CHO}$ cells were transfected with both plasmids for 24 $\mathrm{h}$ and then incubated without additive, or with $10 \mu \mathrm{M}$ ABA, ABA-HP, or ABA-HP plus 100 $\mu \mathrm{M} \mathrm{H}_{2} \mathrm{O}_{2}$ for $30 \mathrm{~min}$. The subcellular localization of the EGFP-PYL fusion protein was monitored under a fluorescence microscope, and the percentage of cells showing nuclear export in each condition was quantified (Figure 2C). EGFP-PYL showed pan-cellular distribution in the absence of ABA and was localized outside of the nucleus when ABA was added. ABA-HP alone did not change the subcellular location of EGFP-PYL. However, the addition of ABA-HP plus $\mathrm{H}_{2} \mathrm{O}_{2}$ caused rapid nuclear export of EGFP-PYL similar to the 
case when ABA was added. When different concentrations of $\mathrm{H}_{2} \mathrm{O}_{2}$ were added, dosagedependent responses were also observed based on the percentage of cells showing nuclear export (Figure 2C). The lowest detection limit for $\mathrm{H}_{2} \mathrm{O}_{2}$ was observed to be around $1 \mu \mathrm{M}$. To characterize and correlate the kinetics of $\mathrm{H}_{2} \mathrm{O}_{2}$-promoted ABA-HP cleavage and $\mathrm{H}_{2} \mathrm{O}_{2}$ induced protein translocation, the ABA-HP cleavage and the EGFP-PYL nuclear export were monitored immediately after $\mathrm{ABA}-\mathrm{HP}$ and $\mathrm{H}_{2} \mathrm{O}_{2}$ addition (from 5 to 30 min, Supplementary Figure S11). Followed by HPLC, we observed that ABA was rapidly generated in $5 \mathrm{~min}$, and the amount was increased with longer incubation periods. It correlated well with the observation that the EGFP nuclear export occurred at around 5 min, and the percentage of cells showing EGFP-PYL translocation also increased with longer incubation periods. These results indicate fast kinetics of ABA-induced dimerization between PYL and ABI. To determine changes at the single cell level, we performed live-cell imaging using a confocal microscope and quantified the fluorescence intensity inside and outside the nucleus of a cell at different time points after $\mathrm{ABA}$ or ABA-HP plus $\mathrm{H}_{2} \mathrm{O}_{2}$ was added to the transfected cells (Supplementary Figure S12). Consistent with previous observations, cells started to show decreased fluorescence intensity in the nucleus at around 5 min and continuing to decrease thereafter. These results demonstrate that we can link the $\mathrm{H}_{2} \mathrm{O}_{2}$ signal to the translocation of a protein to a chosen subcellular location. Several localization signal peptides have been reported, ${ }^{31}$ which can be used in our system to transport chosen proteins to different subcellular locations upon the stimulation of $\mathrm{H}_{2} \mathrm{O}_{2}$.

With this rapidly responsive protein translocation assay at hand, we re-evaluated the stability of ABA-HP against esterases in biological environments (both in cells and in the serum). $\mathrm{CHO}$ cells were transfected with the inducible nuclear export DNA constructs for $24 \mathrm{~h}$ and then incubated either with ABA-HP for 30 min to $4 \mathrm{~h}$ or with ABA-HP that was preincubated (for $30 \mathrm{~min}$ to $4 \mathrm{~h}$ at $37^{\circ} \mathrm{C}$ ) with nonheat-inactivated fetal bovine serum (FBS) for 30 min in cells (Supplementary Figure S13). The nuclear export of EGFP-PYL was used as an indication of the ABA-HP hydrolysis. It was found that ABA-HP was relatively stable in cells within $30 \mathrm{~min}$ as only a minimal percentage of cells showed nuclear export. To rule out the possibility that there may be endogenous $\mathrm{H}_{2} \mathrm{O}_{2}$ that could also cleave ABA-HP to give $\mathrm{ABA}$, control experiments were conducted in which cells were pretreated with catalase, an enzyme that has been used to quench $\mathrm{H}_{2} \mathrm{O}_{2}$ in cellular experiments, ${ }^{32}$ for $1 \mathrm{~h}$ before adding ABA-HP. No difference in the percentages of cells showing nuclear export was observed with or without catalase pretreatment. These results suggest that the observed ABA-HP hydrolysis is likely caused by esterases. To our surprise, ABA-HP that was preincubated with FBS up to $4 \mathrm{~h}$ did not lead to obvious nuclear export when incubated in cells for $30 \mathrm{~min}$. If any cleavage of ABA-HP caused by FBS occurred before adding to cells, a much higher ratio of cells showing nuclear export would be expected. This observation suggests that ABA-HP is stable in FBS for at least $4 \mathrm{~h}$. The difference in results between the incubation in cells and in FBS may likely be due to the different level of esterases in each condition.

To further investigate whether we can integrate the de novo $\mathrm{H}_{2} \mathrm{O}_{2}$ signal components into an endogenous signaling network, we examined the possibility of routing the $\mathrm{H}_{2} \mathrm{O}_{2}$ signal to induce membrane ruffling through the activation of the endogenous Rac1 signaling pathway. Tiam1 is a guanine exchange factor for Rac1, which is a member of Rho GTPase. The 
membrane translocation of Tiam1 activates Rac1 signaling and induces ruffle formation. ${ }^{33}$ We constructed an ABA-inducible Tiam1 membrane localization system, which consists of DNA plasmids encoding the membrane-localized ABI (myr-ABI) ${ }^{12}$ and the cytoplasmic EGFP/PYL-fused Tiam1 (PYL-EGFP-Tiam1) (Figure 2Aiii). CHO cells were transfected with these plasmids for $24 \mathrm{~h}$ and then incubated for 30 min without additive, or with $10 \mu \mathrm{M}$ ABA, ABA-HP, or ABA-HP plus $100 \mu \mathrm{M} \mathrm{H}_{2} \mathrm{O}_{2}$. The ruffle formation was analyzed by counting the number of cells showing morphological changes among all EGFP positive cells using a confocal microscope. As expected, only when cells were treated with ABA, or ABA$\mathrm{HP}$ plus $\mathrm{H}_{2} \mathrm{O}_{2}$, did they show increased ruffle formation (Figure 2D). Either ABA-HP or $\mathrm{H}_{2} \mathrm{O}_{2}$ alone gave background levels of ruffling similar to those without drug addition. These results indicate that the ruffling was caused by the presence of free ABA instead of by $\mathrm{H}_{2} \mathrm{O}_{2}$ alone. To further confirm that the observed ruffling was induced through activating the endogenous Rac1 signaling, the transfected cells were treated with a Rac1 inhibitor, NSC $23766(50 \mu \mathrm{M})$, for $1 \mathrm{~h}$ before adding ABA or ABA-HP plus $\mathrm{H}_{2} \mathrm{O}_{2}$. NSC 23766 is known to block the binding between Tiam 1 and Rac1 and inhibit the activation of Rac1 signaling. ${ }^{34}$ The NSC 23766 treatment lead to decreases in the percentage of cells showing ruffling in both cases of ABA and ABA-HP plus $\mathrm{H}_{2} \mathrm{O}_{2}$ addition (Figure 2D), which indicated that the Tiam1-activated Rac1 signaling was indeed involved in the observed $\mathrm{H}_{2} \mathrm{O}_{2}$-induced ruffling. To examine whether the degree of ruffling can be reduced to the background level, we used higher concentrations of NSC 23766, which, however, led to severe cell death. Alternatively, when we treated cells with lower concentrations of ABA-HP $(5 \mu \mathrm{M})$ and $\mathrm{H}_{2} \mathrm{O}_{2}(50 \mu \mathrm{M})$, the ruffling was indeed reduced to the background level with the NSC $23766(50 \mu \mathrm{M})$ treatment (Supplementary Figure S14). Overall, the above results demonstrate that our approach enabled an endogenous signaling pathway to become responsive to a new signal (i.e., $\mathrm{H}_{2} \mathrm{O}_{2}$ ), which is not normally associated with the pathway in the tested cell type.

We next tested whether the created $\mathrm{H}_{2} \mathrm{O}_{2}$ signaling system can respond to endogenously generated $\mathrm{H}_{2} \mathrm{O}_{2}$ instead of exogenously applied $\mathrm{H}_{2} \mathrm{O}_{2}$ as in previous experiments. It has been reported that $\mathrm{A} 431$ cells can be stimulated by epidermal growth factor (EGF) to produce $\mathrm{H}_{2} \mathrm{O}_{2}$ in micromolar concentrations. ${ }^{35,36} \mathrm{~A} 431$ cells were transfected with the inducible EGFP nuclear export DNA constructs for $24 \mathrm{~h}$ and then treated with no drug, ABA-HP alone, $10 \mu \mathrm{M}$ ABA-HP plus $100 \mu \mathrm{M} \mathrm{H}_{2} \mathrm{O}_{2}$, or $10 \mu \mathrm{M}$ ABA-HP plus 500 or 1000 $\mathrm{ng} / \mathrm{mL}$ of EGF. The percentage of cells showing EGFP-PYL nuclear export in each condition was then quantified using a fluorescence microscope. The EGFP nuclear export was readily detected within $30 \mathrm{~min}$ after EGF stimulation, which was similar to the case when cells were stimulated by exogenous $\mathrm{H}_{2} \mathrm{O}_{2}$ (Figure 2E). No obvious EGFP nuclear export was observed without EGF stimulation. To confirm that $\mathrm{H}_{2} \mathrm{O}_{2}$ was indeed generated by the EGF stimulation to give the observed EGFP-PYL translocation, the EGF-stimulated cells were treated with catalase for $1 \mathrm{~h}$ before adding ABA-HP. The level of EGFP nuclear export was found to reduce to a level similar to the case when cells were treated with ABA$\mathrm{HP}$ only (without $\mathrm{H}_{2} \mathrm{O}_{2}$ or EGF) (Figure 2E). These results clearly demonstrate that the engineered $\mathrm{H}_{2} \mathrm{O}_{2}$ signaling system can respond to the $\mathrm{H}_{2} \mathrm{O}_{2}$ generated endogenously in cells.

We expect that the same strategy can be expanded to other CIP inducers, which will allow us to build orthogonal signaling pathways in the same cell and potentially to construct crosstalking pathways. To test this possibility, we applied this strategy to the GA-based CIP 
system. GA induces the binding between GAI and GID1 proteins in a similar way as ABA does. ${ }^{37} \mathrm{GA}$ has been developed as an orthogonal CIP system that was used to perform cellular computing. ${ }^{13} \mathrm{GA}$ is not cell permeable. It was modified as the acetoxymethoxy ester (GA-AM) to cross the cell membrane and subsequently be cleaved by esterases to generate functional GA. ${ }^{13}$ It has been shown that the carboxylate group on GA is critical for its biological functions. A minor modification that converts the carboxylate into a nonhydrolyzable hydroxamate abolishes its CIP activity. ${ }^{13}$ A recent report also showed that photolabile groups can be linked to the carboxylate group on GA to cage its activity. ${ }^{38} \mathrm{We}$ expect that modifying this carboxylate group of $\mathrm{GA}$ with the $\mathrm{H}_{2} \mathrm{O}_{2}$-sensitive boronate probe will give an $\mathrm{H}_{2} \mathrm{O}_{2}$-responsive GA system. We synthesized GA-HP by coupling the boronate group to GA (Figure 3A). We analyzed the chemical stability of GA-HP and its conversion back to $\mathrm{GA}$ upon $\mathrm{H}_{2} \mathrm{O}_{2}$ addition using HPLC. In the presence of $\mathrm{H}_{2} \mathrm{O}_{2}$, GA was rapidly regenerated from GA-HP within $2 \mathrm{~h}$ (Figure 3B, Supplementary Figure S15). It was observed that, without $\mathrm{H}_{2} \mathrm{O}_{2}$, GA-HP did not release GA when incubated in HEPES buffer for $24 \mathrm{~h}$, although the boronate group was partially hydrolyzed as reported in a similar case to give an inert but convertible product (Supplementary Figures S16 and S17). ${ }^{39}$ We also tested the selectivity of GA-HP against different ROS and cellular metals and found that GA-HP was selective for $\mathrm{H}_{2} \mathrm{O}_{2}$ among tested molecules (Supplementary Figures S18 and S19).

To examine if we can produce biologically active GA from GA-HP in the presence of $\mathrm{H}_{2} \mathrm{O}_{2}$ in cells, we made DNA constructs to encode a nuclear exported GID1 (NES-GID1) and a pan-cellular distributed EGFP-tagged GAI (EGFP-GAI) (Figure 3C). CHO cells were transfected with these plasmids for $24 \mathrm{~h}$ and then incubated without additive or with $100 \mu \mathrm{M}$ GA-AM, GA-HP, or GA-HP plus $100 \mu \mathrm{M} \mathrm{H} \mathrm{H}_{2} \mathrm{O}_{2}$ for 30 min. The percentage of cells showing EGFP-GAI nuclear export was quantified in each condition using a fluorescence microscope (Figure 3D). Only cells treated with GA-AM or GA-HP plus $\mathrm{H}_{2} \mathrm{O}_{2}$ showed nuclear export, which indicated that functional GA was generated from GA-HP upon $\mathrm{H}_{2} \mathrm{O}_{2}$ addition. Given that GA cannot cross the cell membrane, the observed intracellular effects suggested that the $\mathrm{H}_{2} \mathrm{O}_{2}$-induced cleavage of GA-HP occurred inside the cells. The successful implementation of this strategy using GA demonstrates the potential generality of our strategy.

In conclusion, we have developed a novel strategy integrating CIP methods and $\mathrm{H}_{2} \mathrm{O}_{2}$ sensing to construct de novo cell signaling pathways that redirected $\mathrm{H}_{2} \mathrm{O}_{2}$ to control different cellular processes (i.e., transcription and protein translocation) or to interface with an existing endogenous signaling circuit (i.e., the Rac1 signaling). We have showed that ABA can be converted to become responsive to exogenous or endogenous $\mathrm{H}_{2} \mathrm{O}_{2}$ stimulation rapidly and specifically at physiologically relevant concentrations. Moreover, this strategy can be generally applied to different CIP inducers (i.e., ABA and GA). It provides the potential to expand this strategy in building signaling networks when each orthogonal CIP inducer is designed to become activated by a unique signal. We expect that sensing units for different cell signals can be used to replace the $\mathrm{H}_{2} \mathrm{O}_{2}$ sensing unit used in this study to switch the responding specificity. ${ }^{40,41}$ We believe that our novel strategy to engineer de novo cell signaling circuits will have wide applications in the fields of cell signaling research, biocomputing, and synthetic biology and contribute to the future development of gene and cell therapies for human diseases. 


\section{METHODS}

Methods and any associated references are available in the Supporting Information.

\section{Supplementary Material}

Refer to Web version on PubMed Central for supplementary material.

\section{Acknowledgments}

We thank the Michael J. Fox Foundation (to F.-S.L. and W.W.), the University of New Mexico (to F.-S.L.), and the Shin Fellowship (to G.Z.) for financial support.

\section{References}

1. Bashor CJ, Horwitz AA, Peisajovich SG, Lim WA. Rewiring cells: synthetic biology as a tool to interrogate the organizational principles of living systems. Annu Rev Biophys. 2010; 39:515-537. [PubMed: 20192780]

2. Purnick PE, Weiss R. The second wave of synthetic biology: from modules to systems. Nat Rev Mol Cell Biol. 2009; 10:410-422. [PubMed: 19461664]

3. Haynes KA, Silver PA. Eukaryotic systems broaden the scope of synthetic biology. J Cell Biol. 2009; 187:589-596. [PubMed: 19948487]

4. Auslander S, Auslander D, Muller M, Wieland M, Fussenegger M. Programmable single-cell mammalian bio-computers. Nature. 2012; 487:123-127. [PubMed: 22722847]

5. Miyamoto T, Razavi S, DeRose R, Inoue T. Synthesizing biomolecule-based Boolean logic gates. ACS Synth Biol. 2013; 2:72-82. [PubMed: 23526588]

6. Aubel D, Fussenegger M. Mammalian synthetic biology: from tolls to therapies. Bio Essays. 2009; 32:332-345.

7. Ruder WC, Lu T, Collins JJ. Synthetic biology moving into clinic. Science. 2011; 333:1248-1252. [PubMed: 21885773]

8. Lim WA. Designing customized cell signaling circuits. Nat Rev Mol Cell Biol. 2010; 11:393-403. [PubMed: 20485291]

9. Fegan A, White B, Carlson JCT, Wagner CR. Chemically controlled protein assembly: techniques and applications. Chem Rev. 2010; 110:3315-3336. [PubMed: 20353181]

10. Gestwicki JE, Marinec PS. Chemical control over protein-protein interactions: beyond inhibitors. Comb Chem High Throughput Screening. 2007; 10:667-675.

11. DeRose R, Miyamoto T, Inoue T. Manipulating signalling at will: chemically-inducible dimerization (CID) techniques resolve problems in cell biology. Pflugers Arch. 2013; 465:409417. [PubMed: 23299847]

12. Liang F-S, Ho WQ, Crabtree GR. Engineering the ABA plant stress pathway for regulation of induced proximity. Sci Signal. 2011; 4:rs2. [PubMed: 21406691]

13. Miyamoto T, DeRose R, Suarez A, Ueno T, Chen M, Sun T, Wolrgang MJ, Mukherjee C, Meyers DJ, Inoue T. Rapid and orthogonal logic gating with a gibberellin-induced dimerization system. Nat Chem Biol. 2012; 8:465-470. [PubMed: 22446836]

14. Stone JR, Yang S. Hydrogen peroxide: a signaling messenger. Antioxid Redox Signal. 2006; 8:243-270. [PubMed: 16677071]

15. Rice ME. H2O2, a dynamic neuromodulator. Neuroscientist. 2011; 17:389-406. [PubMed: 21666063]

16. Xiao Q, Luo Z, Pepe AE, Margariti A, Zeng L, Xu Q. Embryonic stem cell differentiation into smooth muscle cells is mediated by Nox4-produced H2O2. Am J Physiol, Cell Physiol. 2009; 296:C711-23. [PubMed: 19036941] 
17. Nindl G, Peterson NR, Hughes EF, Waite LR, Johnson MT. Effect of hydrogen peroxide on proliferation, apoptosis and interleukin-2 production of Jurkat T cells. Biomed Sci Instrum. 2004; 40:123-128. [PubMed: 15133946]

18. López-Lázaro M. Dual role of hydrogen peroxide in cancer: possible relevance to cancer chemoprevention and therapy. Cancer Lett. 2007; 252:1-8. [PubMed: 17150302]

19. Lee J, Giordano S, Zhang J. Autophagy, mitochondria and oxidative stress: cross-talk and redox signaling. Biochem J. 2012; 441:523-540. [PubMed: 22187934]

20. Miyazono K, Miyakawa T, Sawano Y, Kubota K, Kang H, Asano A, Miyauchi Y, Takahashi M, Zhi Y, Fujita Y, Yoshida T, Kodaira K, Yamaguchi-Shinozaki K, Tanokura M. Structural basis of abscisic acid signaling. Nature. 2009; 462:609-614. [PubMed: 19855379]

21. Wright WC, Guo ZF, Liang FS. Light control of cellular processes by using photocaged abscisic acid. Chem Bio Chem. 2015; 16:254-261.

22. Lippert AR, Van de Bittner GC, Chang CJ. Boronate oxidation as a bioorthogonal reaction approach for studying the chemistry of hydrogen peroxide in living systems. Acc Chem Res. 2011; 44:793-804. [PubMed: 21834525]

23. Govan JM, McIver AL, Riggsbee C, Deiters A. Hydrogen peroxide induced activation of gene expression in mammalian cells using boronate estrone derivatives. Angew Chem, Int Ed. 2012; 51:9066-9070.

24. Weinstain R, Savariar EN, Felsen CN, Tsien RY. In vivo targeting of hydrogen peroxide by activatable cell-penetrating peptides. J Am Chem Soc. 2014; 136:874-877. [PubMed: 24377760]

25. Spanos M, Gras-Najjar J, Letchworth JM, Sanford AL, Toups JV, Sombers LA. Quantitation of hydrogen peroxide fluctuations and their modulation of dopamine dynamics in the rat dorsal striatum using fast-scan cyclic voltammetry. ACS Chem Neurosci. 2013; 4:782-789. [PubMed: 23556461]

26. Hyslop PA, Zhang Z, Pearson DV, Phebus LA. Measurement of striatal $\mathrm{H}_{2} \mathrm{O}_{2}$ by microdialysis following global forebrain ischemia and reperfusion in the rat: correlation with the cytotoxic potential of $\mathrm{H}_{2} \mathrm{O}_{2}$ in vitro. Brain Res. 1995; 671:181-186. [PubMed: 7743206]

27. Gill RS, Lee TF, Liu JQ, Chaudhary H, Brocks DR, Bigam DL, Cheung P. Cyclosporine treatment reduces oxygen free radical generation and oxidative stress in the brain of hypoxia-reoxygenated newborn piglets. PLoS One. 2012; 7:e40471. [PubMed: 22792343]

28. Mueller S, Riedel HD, Stremmel W. Determination of catalase activity at physiological hydrogen peroxide concentrations. Anal Biochem. 1997; 245:55-60. [PubMed: 9025968]

29. Imlay JA. Cellular defenses against superoxide and hydrogen peroxide. Annu Rev Biochem. 2008; 77:755-776. [PubMed: 18173371]

30. Kusaka N, Maisch J, Nick P, Hayashi K, Nozaki H. Manipulation of intracellular auxin in a single cell by light with esterase-resistant caged auxin. Chem Bio Chem. 2009; 10:2195-2202.

31. Heijine GV. Signal Pept. 200510.1038/npg.els.0005050

32. Martinez-Outschoorn UE, Lin Z, Trimmer C, Flomenberg N, Wang C, Pavlides S, Lisanti MP. Cancer cells metabolically "fertilize" the tumor microenvironment with hydrogen peroxide, driving the Warburg effect: implications for PET imaging of human tumors. Cell Cycle. 2011:2504-2520. [PubMed: 21778829]

33. Michiels F, Habets GG, Stam JC, van der Kammen RA, Collard JG. A role for Rac in Tiam1induced membrane ruffling and invasion. Nature. 1995; 375:338-340. [PubMed: 7753201]

34. Fu L, Jiang C, Davis JS. Insulin-like growth factor 1 promotes cancer cell growth via RAC1 activation in ovarian epithelial cancer cells. Cancer Res. 2012; 72:3915-3915.

35. Jin H, Heller DH, Kalbacova M, Kim JH, Zhang J, Boghossian AA, Maheshri N, Strano MS. Detection of single-molecule $\mathrm{H}_{2} \mathrm{O}_{2}$ signalling from epidermal growth factor receptor using fluorescent single-walled carbon nanotubes. Nat Nanotechnol. 2010; 5:302-309. [PubMed: 20208549]

36. Bae YS, Kang SW, Seo MS, Baines IC, Tekle E, Chock PB, Rhee SG. Epidermal growth factor (EGF)-induced generation of hydrogen peroxide. J Biol Chem. 1997; 272:217-221. [PubMed: 8995250] 
37. Shimada A, Ueguchi-Tanaka M, Nakatsu T, Nakajima M, Naoe Y, Ohmiya H, Kato H, Matsuoka M. Structural basis for gibberellin recognition by its receptor GID1. Nature. 2008; 456:520-523. [PubMed: 19037316]

38. Schelkle KM, Griesbaum T, Ollech D, Becht S, Buckup T, Hamburger M, Wombacher R. Lightinduced protein dimerization by one- and two-photon activation of gibberellic acid derivatives in living cells. Angew Chem, Int Ed. 2015; 54:2825-2829.

39. Song CC, Ji R, Du FS, Liang DH, Li ZC. Oxidation-accelerated hydrolysis of the ortho estercontaining acid-labile polymers. ACS Macro Lett. 2013; 2:273-277.

40. Chan J, Dodani SC, Chang CJ. Reaction-based small-molecule fluorescent probes for chemoselective bioimaging. Nat Chem. 2012; 4:973-984. [PubMed: 23174976]

41. Choi KY, Swierczewska M, Lee S, Chen X. Protease-activated drug development. Theranostics. 2012; 2:156-178. [PubMed: 22400063] 

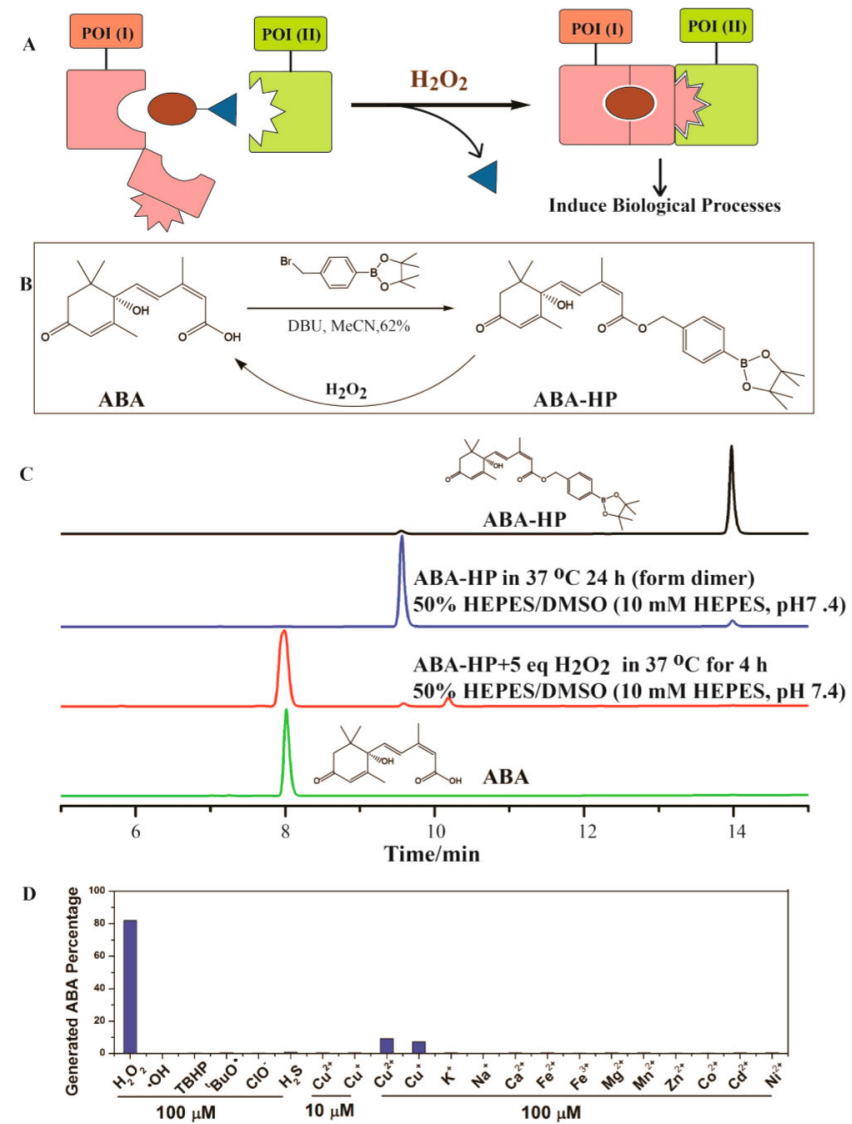

Figure 1.

(A) General process for $\mathrm{H}_{2} \mathrm{O}_{2}$-induced proximity to control biological processes. (B) Synthesis of ABA-HP and its conversion to ABA in the presence of $\mathrm{H}_{2} \mathrm{O}_{2}$. (C) ABA-HP (1 $\mathrm{mM}$ ) was treated with or without $5 \mathrm{mM} \mathrm{H}_{2} \mathrm{O}_{2}$ for indicated time periods. (D) ABA-HP (100 $\mu \mathrm{M})$ was incubated with $100 \mu \mathrm{M}$ of indicated molecules for $4 \mathrm{~h}$ at $37^{\circ} \mathrm{C}$. Error bars are SD $(N=3)$. 

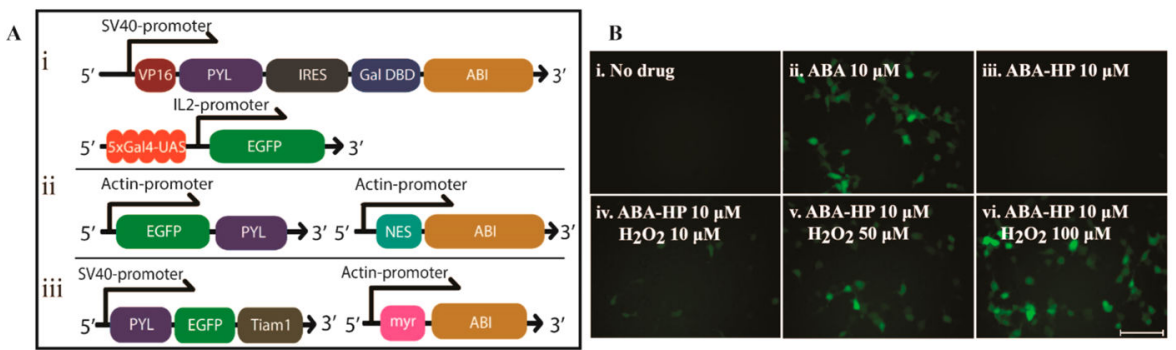
C Representative pictures of cells showing
uninduced or induced phenotype
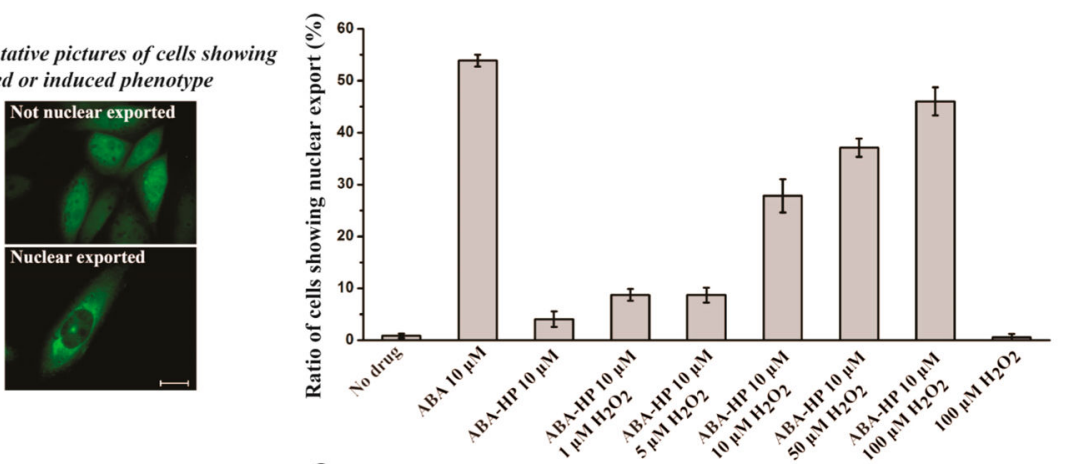

D

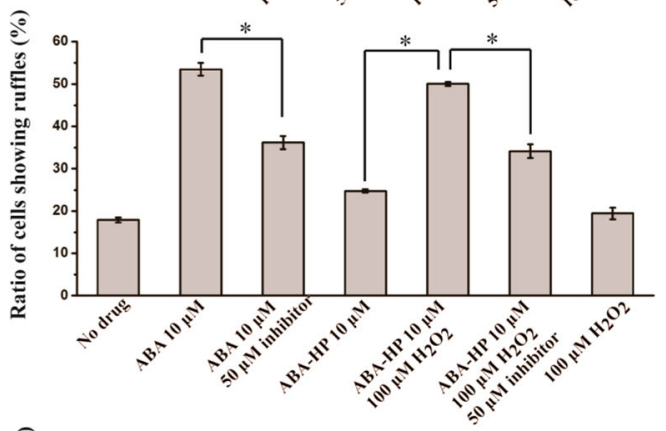

Representative pictures of cells showing uninduced or induced phenotype

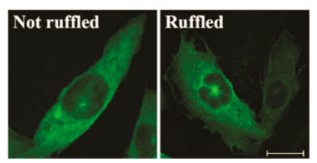

E Representative pictures of cells showing uninduced or induced phenotype Not nuclear exported

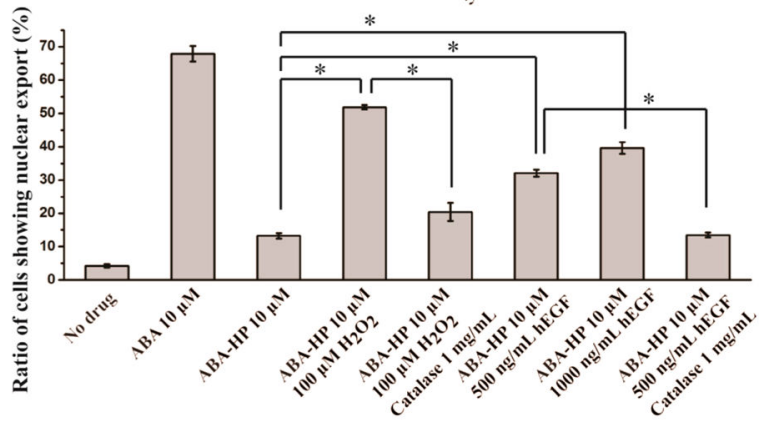

Figure 2.

(A) DNA constructs for (i) EGFP expression, (ii) EGFP nuclear export, and (iii) Rac1 signaling/ruffle formation. (B) EGFP expression in HEK293T cells under different treating conditions (10 h). (C) Nuclear export of EGFP in CHO cells under different treating conditions (30 min). (D) Ruffle formation of $\mathrm{CHO}$ cells under different treating conditions (30 min). (E) Nuclear export of EGFP in A431 cells under different treating conditions. The statistical data was obtained by counting cells to give the percentage of cells showing nuclear export or ruffling over the total EGFP positive cells. Cells were counted from three separate experiments each with five different areas chosen randomly, and over 700 cells 
were counted for each sample. Scale bar is $100 \mu \mathrm{m}$ (B) and $20 \mu \mathrm{m}$ (C-E). Error bars are SD $(N=3) . * P$-value $<0.001$. 
A

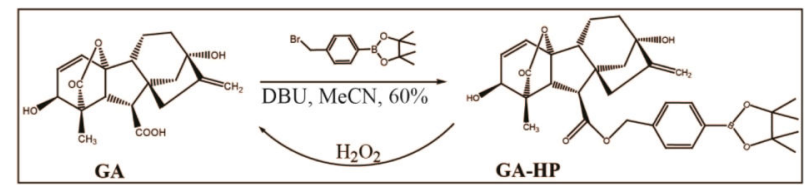

B

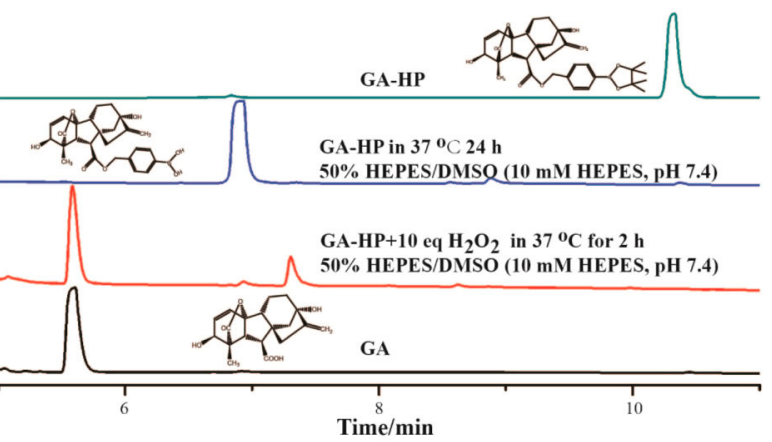

C

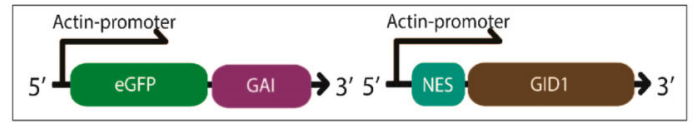

Depresentative pictures of
cells showing uninduced cells showing uninduced
or induced phenotype
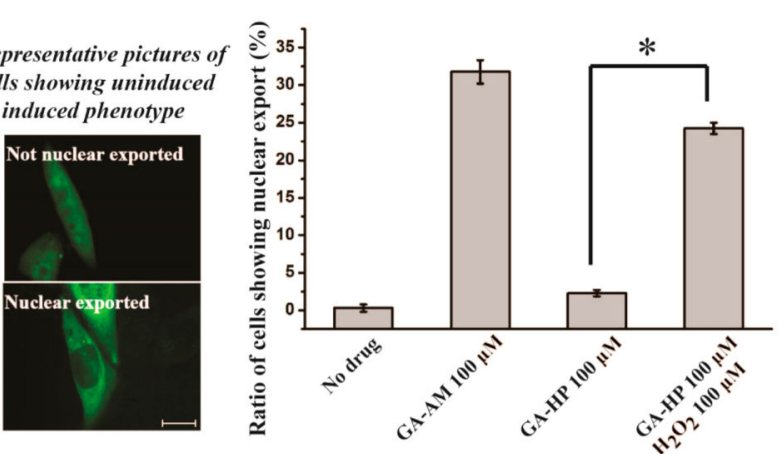

Figure 3.

(A) Synthesis of GA-HP and its conversion to GA in the presence of $\mathrm{H}_{2} \mathrm{O}_{2}$. (B) GA-HP (5 $\mathrm{mM}$ ) was treated with or without $50 \mathrm{mM}$ of $\mathrm{H}_{2} \mathrm{O}_{2}$ for indicated time periods. (C) DNA constructs for EGFP nuclear export and (D) the nuclear export of EGFP in CHO cells under different treating conditions $(30 \mathrm{~min}$ ). The statistical data was obtained by counting cells to give the percentage of cells showing nuclear export over the total EGFP positive cells. Cells were counted from three separate experiments each with five different areas chosen randomly, and over 700 cells were counted for each sample. Scale bar is $20 \mu \mathrm{m}$ (D). Error bars are $\operatorname{SD}(N=3)$. $* P$-value $<0.001$. 